\title{
PENGARUH FIRM SIZE, CURRENT RATIO, PROFITABILITAS, DAN HUTANG HARGA SAHAM DENGAN DEVIDEN SEBAGAI MODERATING VARIABEL
}

\author{
Siti Khuswatun Khasanah \\ Program Akuntansi, Universitas Trisakti, Jakarta \\ Diterima 18 Februari 2019 / Disetujui 20 Maret 2019
}

\begin{abstract}
The purpose of this study is to get a picture of the DPR moderating both partially and simultant on the Effect of DER, ROA, Firm Size on PER. The research approach used is a quantitative research approach. This type of research is documentation research while the nature of research is quantitative correlative. The target population of the study is the Manufacture Sector Sub Sector Consumer Goods Company in the Indonesia Stock Exchange, which amounted to 38 (thirty eight) issuers. While the sampling collection technique is a nonprobability-purposive sampling so that the number of sample research targets is four issuers. The data analysis techniques applied include: 1. Descriptive Statistic Analysis; 2. Partial Regression Analysis; 3. Multiple Regression Analysis; and 4. Moderate Regression Analysis Model. the results of hypothesis testing through the $t$ test, show that partially. DPR is able to moderate the influence of DER, ROA, Firm Size on PER. Whereas from the F test shows that simultant, the DPR is able to moderate the Effect of DER, ROA and Firm Size on PER. In this case, DER is a dominant and significant dominant predictor of PER.
\end{abstract}

Keyword: Dividend Payout Ratio, Price Earning Ratio.

\begin{abstract}
ABSTRAK
Tujuan penelitian ini adalah untuk mendapatkan gambaran DPR memoderasi baik secara partial maupun secara simultant pada Pengaruh DER, ROA, Firm Size Terhadap PER. Pendekatan penelitian yang digunakan adalah pendekatan penelitian kuantitatif. Jenis penelitian adalah penelitian dokumentasi sedangkan sifat penelitian adalah korelatif kuantitatif. Populasi sasaran penelitian adalah Perusahaan Sektor Manufacture Sub Sector Consumer GoodsListing di Bursa Efek Indonesia yang berjumlah 38 (tiga puluh delapan) emiten. Sedangkan teknik penarikan sampling penelitian adalah non probability-purposive sampling sehingga jumlah sampel sasaran penelitian adalah empat emiten. Teknik analisis data yang diterapkan meliputi: 1. Descriptive Statistic Analysis; 2. Partial Regression Analysis; 3. Multiple Regression Analysis; dan 4. Moderate Regression Analysis Model. hasil uji hipotesis melalui uji t, menunjukkan bahwa secara partial. DPR mampu memoderasi Pengaruh DER, ROA, Firm Size Terhadap PER. Sedangkan dari uji F menunjukkan bahwa secara simultant, DPR mampu memoderasi Pengaruh DER, ROA dan Firm Size Terhadap PER. Dalam hal ini, DER merupakan predictor dominant yang positif dan signifikan terhadap PER.
\end{abstract}

Keyword: Dividend Payout Ratio, Price Earning Ratio.

\footnotetext{
*Korespondensi Penulis:

e-mail: uswahahmad21@gmail.com
} 


\section{PENDAHULUAN}

Bila mencermati dinamika perdagangan dunia, ditengarai transaksi consumer goods khususnya barang konsumsi dengan pergerakan cepat (Fast Moving Consumer Goods atau FMCG) mengusai perdagangan dunia. Fast Moving Consumer Goods (FMCG) merupakan barang-barang non durable yang diperlukan untuk penggunaan sehari-hari. Konsumen biasanya membeli produk kategori Fast Moving Consumer Goods (FMCG) sekurangnya sekali dalam sebulan. Ditengarai, di semua negara, konsumen mengeluarkan anggaran paling besar pada sektor Fast Moving Consumer Goods (FMCG).

Dalam literasi, produk Fast Moving Consumer Goods (FMCG) dapat dikelompokkan dalam tiga kategori sebagai berikut: (1) Perawatan Pribadi (Personal Care) antara lain adalah pasta gigi, shampoo, kosmetik, parfum; (2) Perlengkapan Rumah Tangga (Household Care) antara lain adalah sabun cuci, pembasmi serangga; dan (3) Makanan dan Minuman (Food and Beverages) antara lain adalah minuman ringan, teh, kopi, sayuran.

Di Tahun 2017 lalu, lembaga riset Kantar World Panel merilis Top Ten Brand Footprint Indonesia sebagai berikut: pertama adalah Indomie produk Indofood sebagai brand nomor satu yang paling dipilih konsumen Indonesia di perkotaan besar; kedua adalah brand penyedap masakan Royco produk Unilever; ketiga, Mie Sedaap produk Wings Food; (4) keempat adalah Frisian Flag produk PT. Frisian Flag; (5) kelima adalah sabun detergent So Klin produk Wings; keenam adalah Kopi Kapal Api produk PT. Santos Jaya Abadi; ketujuh adalah minyak goreng Bimoli produk Indofood; kedelapan adalah bumbu masak Masako produk PT. Ajinomoto Indonesia; kesembilan adalah sabun mandi Lifebouy produk Unilever; dan kesepuluh adalah sabun detergent Rinso produk Unilever.

Dengan mencermati Top Ten Brand Footprint Indonesia di atas, maka bisa dikatakan bahwa mayoritas Fast Moving Consumer Goods (FMCG) adalah berkutat di Household Care dan Food and Beverages yang didominasi oleh Indofood dan Unilever. Kedua korporasi tersebut masuk dalam
Listing LQ 45 sektor Manufaktur Consumer Good di Bursa Efek Indonesia.

Consumer Goods khususnya Fast Moving Consumer Goods tumbuh pesat di Indonesia yaitu, Di Tahun 2011, sebesar 11,8\%, Di Tahun 2014 sebesar 15,2 persen. Kemudian di Tahun 2017 mengalami perlambatan sebesar 7.4\%. Perlambatan ini sudah barang tentu berefek pada nilai perusahaan. Ditengarai ada berbagai faktor yang mempengaruhi nilai perusahaan antara lain: adalah struktur modal, kebijakan dividen, dan keputusan investasi.

Mardiyanto (2009: 32) menjelaskan bahwa nilai Perusahaan merupakan nilai sekarang dari serangkaian arus kas masuk yang akan dihasilkan perusahaan pada masa mendatang. Sementara itu, Margaretha (2005; 12) menjelaskan bahwa nilai perusahaan yang sudah go public tercermin dalam harga pasar saham perusahaan. Sedangkan nilai perusahaan yang belum go public nilainya terealisasi apabila perusahaan akan dijual dalam hal ini, total aktiva dan prospek perusahaan, risiko usaha, tingginya nilai pasar dari saham mencerminkan tingginya nilai perusahaan atau sebaliknya.

Sedangkan dari sisi investor, informasi nilai perusahaan penting untuk pengambilan keputusan investasi saham. Mengingat informasi tersebut sangat membantu investor mengetahui saham mana yang bertumbuh dan memiliki kinerja yang baik yang dipresentasikan melalui Price Earning Ratio (PER) dimana menunjukkan berapa banyak jumlah uang yang rela dikeluarkan oleh para investor untuk membayar setiap dolar laba yang dilaporkan (Brigham dan Houston, 2006:110).

Kegunaan Price Earning Ratio (PER) adalah untuk melihat bagaimana pasar menghargai kinerja perusahaan yang dicerminkan oleh Earning Per Share nya. Price Earning Ratio (PER) menunjukkan hubungan antara pasar saham biasa dengan Earning Per Share.

Struktur modal merupakan salah satu kunci pokok keberhasilan sebuah perusahaan adalah manajemen keuangan yang baik. Peran seorang manajer begitu penting dalam pengambilan kebijakan yang tepat agar perusahaan dapat senantiasa mengoptimalkan sumber dananya. Struktur modal merupakan kombinasi dari sumber dana jangka panjang yang dimiliki oleh suatu entitas. 
Dengan demikian profitabilitas mutlak diperlukan untuk perusahaan apabila hendak membayarkan dividen. Tingkat Profitability merupakan informasi yang juga menjadi perhatian investor.

Ada satu faktor yang turut diamati oleh calon investor dalam memnutuskan investasi yaitu ukuran perusahaan (Firm Size) sebagai factor yang dipertimbangkan dalam menentukan nilai perusahaan. Firm Size merupakan cerminan total dari aset yang dimiliki suatu perusahaan. Pertanyaannya,

\section{Rumusan Masalah}

1. Bagaimana, Pengaruh Debt To EquityRatio (DER), Return On Assets (ROA), Firm Size Terhadap Price Earning Ratio (PER) Manufaktur Sektor Consumer Goods Listing LQ 45 di Bursa Efek Indonesia Periode Fiskal 2013-2017?

2. Bagaimana Pengaruh Debt To EquityRatio (DER), Return On Assets (ROA), dan Firm Size Terhadap Price Earning Ratio (PER) Manufaktur Sektor Consumer Goods Listing LQ 45 di Bursa Efek Indonesia Periode Fiskal 2013-2017?

3. Bagaimana Dividend Payout Ratio (DPR) mampu memoderasi secara Partial, Pengaruh Debt To Equity Ratio (DER), Return On Assets (ROA), Firm Size Terhadap Price Earning Ratio (PER) Manufaktur - Sektor Consumer Goods Listing LQ 45 di Bursa Efek Indonesia Periode Fiskal 2013-2017?

4. Pada Tingkat Signifikansi 0.05 , Bagaimana Dividend Payout Ratio (DPR) mampu memoderasi secara Simultant, Pengaruh Debt To EquityRatio (DER), Return On Assets (ROA), dan Firm Size Terhadap Price Earning Ratio (PER) Manufaktur Sektor Consumer Goods Listing LQ 45 di Bursa Efek Indonesia Periode Fiskal 2013-2017?

\section{Tujuan Penelitian}

Tujuan penelitian ini, antara lain: (1) mendapatkan gambaran secara Partial, Pengaruh Debt To EquityRatio (DER), Return On Assets (ROA), Firm Size Terhadap Price Earning Ratio (PER) Manufaktur Sektor Consumer Goods Listing LQ 45 di Bursa Efek Indonesia Periode Fiskal 2013-
2017. (2) Mendapatkan gambaran secara Simultant, bagaimana Pengaruh Debt To EquityRatio (DER), Return On Assets (ROA), dan Firm Size terhadap Price Earning Ratio (PER) Manufaktur - Sektor Consumer Goods Listing LQ 45 di Bursa Efek Indonesia Periode Fiskal 2013-2017, dan (3) mendapatkan gambaran pada Tingkat Signifikansi 0.05, Dividend Payout Ratio (DPR) mampu memoderasi secara Partial, Pengaruh Debt To EquityRatio (DER), Return On Assets (ROA), Firm Size Terhadap Price Earning Ratio (PER) Manufaktur Sektor Consumer Goods Listing LQ 45 di Bursa Efek Indonesia Periode Fiskal 20132017. (4) mendapatkan gambaran pada Tingkat Signifikansi 0.05 Dividend Payout Ratio (DPR) mampu memoderasi secara Simultant, Pengaruh Debt To EquityRatio (DER), Return On Assets (ROA), dan Firm Size Terhadap Price Earning Ratio (PER) Manufaktur - Sektor Consumer Goods Listing LQ 45 di Bursa Efek Indonesia Periode Fiskal 2013-2017.

\section{LANDASAN TEORI}

\section{Dividend}

Menurut M. M. Hanafi (2004:361) menjelaskan dividend merupakan selain Capital Gain, ada kompensasi yang diterima oleh pemegang saham (investor). Dividend ini untuk dibagikan kepada para pemegang saham (investor) sebagai keuntungan dari labaperusahaan.

Sementara itu, menurut Stice Earl K, James D. Stice and K. Fred Skousen(2004:651)menjelaskan bahwa dividend merupakan pembagian laba kepada para pemegang saham perusahaan sebanding dengan jumlah saham yang dipegang oleh masing-masing pemilik. Dividend dapat berupa uang tunai maupun saham.Terkait dengan dividend terdapat tiga tanggal pentingyaitu: a. Pengumuman; b. Pencatatan; dan c. Pembayaran atau pembagian. Kemudian, menurut Z. Baridwan (2000:434) menjelaskan bahwa dividendmerupakan proporsi laba atau keuntungan yang dibagikan kepada para pemegang saham (investor) dalam jumlah yang sebanding dengan jumlah lembar saham yang dimilikinya.

Dari uraian di atas, peneliti dapat menarik sintesa bahwa yang dimaksud dengan pengertian Dividend merupakan keuntungan yang diberikan pada para 
pemegang saham yang bersumber dari kemampuan emiten mencetak laba bersih dari operasinya.

2. Nilai Perusahaan

Sujoko dan Soebiantoro (2007: 12) menjelaskan bahwa Nilai perusahaan merupakan persepsi investor terhadap tingkat keberhasilan perusahaan yang terkait erat dengan harga sahamnya.

Sedangkan menurut Mardiyanto (2009: 32), Nilai Perusahaan merupakan nilai sekarang dari serangkaian arus kas masuk yang akan dihasilkan perusahaan pada masa mendatang. Margaretha (2005: 12) menjelaskan juga bahwa Nilai Perusahaan yang sudah go public tercermin dalam harga pasar saham perusahaan.

Dari beberapa definisi di atas dapat disimpulkan bahwa nilai perusahaan adalah suatu kondisi tertentu yang telah dicapai oleh suatu perusahaan yang tercermin dalam harga pasar saham perusahaan tersebut.

Pada penelitian ini, proxy yang digunakan untuk Nilai Perusahaan melalui formulasi Price Earning Ratio (PER) sebagai berikut:

$$
\mathrm{PER}=\frac{\text { Harga Saham }}{\text { Laba Per Lembar Saham }} x 100 \%
$$

\section{Struktur Modal}

Menurut J. LawrenceGitman (2000; 488), Struktur Modal merupakan capital structure is the mix of long term debt and equity maintained by the firm.

Menurut Riyanto (1984, 4), struktur modal harus dapat dibedakan dengan struktur keuangan. Struktur keuangan menyatakan dengan bagaimana harta perusahaan dibiayai. Oleh karena itu struktur keuangan adalah keseluruhan yang terdapat di dalam neraca sebelah kredit. Pada neraca sebelah kredit terdapat hutang jangka panjang maupun hutang jangka pendek, dan modal sendiri (Equity) baik jangka panjang maupun jangka pendek.

Adapun formulasi untuk mencari Debt To EquityRatio dapat digunakan perbandingan antaraTotal Liquidities dengan Total Equity.

$$
\text { DER }=\frac{\text { Total Liabilities }}{\text { Total Equity }} \times 100 \%
$$

4. Profitabilitas

Menurut Husnan (2001: 36)Profitabilitas adalah kemampuan suatu perusahaan dalam menghasilkan keuntungan (Profit) pada tingkat penjualan, Asset dan Modal saham tertentu. Profitabilitas

Munawir (2010: 45) Profitabilitas adalah rasio yang menunjukkan kemampuan perusahaan untuk menghasilkan laba selama periode tertentu. Profitabilitas suatu perusahaan diukur dengan kesuksesan perusahaan dan kemampuan menggunakan aktivanya secara produktif, dengan demikian profitabilitas

Menurut Margaretha (2014: 34) bahwa rasio profitabilitas merupakan rasio yang digunakan untuk menilai kemampuan perusahaan dalam mencari keuntungan atau laba dalam suatu periode tertentu. Pada penelitian ini, Profitability direpresentasikan dalam wujud Return On Assets (ROA).

ROA $=\frac{\text { Laba Bersih Setelah Pajak }}{\text { Total Aktiva }} \times 100 \%$

5. Ukuran Perusahaan (Firm Size)

Menurut Brigham and Houston (2010: 4) ukuran perusahaan (Firm Size) merupakan ukuran besar kecilnya sebuah perusahaan yang ditunjukan atau dinilai oleh total asset, total penjualan, jumlah laba, beban pajak dan lain-lain. Menurut Hartono (2008: 14) ukuran perusahaan (Firm Size) merupakan besar kecilnya perusahaan dapat diukur dengan total aktiva atau besar harta perusahaan dengan menggunakan perhitungan nilai logaritma total aktiva. Menurut Torang (2012: 93) adalah ukuran organisasi adalah menentukan jumlah anggota yang

Menurut Consoladi (Heni Oktaviani, 2014: 32) mengatakan bahwa: ukuran perusahaan dapat mempengaruhi kinerja sosial perusahaan karena perusahaan yang besar mempunyai pandangan yang lebih jauh, sehingga lebih berpartisipasi dalam menumbuhkan kinerja sosial perusahaan.

Adapun Formulasi Ukuran Perusahaan (Firm Size) sebagai berikut:

\section{FIRM SIZE $=$ LN Total Asset}

6. Kebijakan Dividen 
Menurut Sundjaja dan Barlin (2010: 388) terdapat tiga jenis kebijakan dividen sebagai berikut:

a. Kebijakan Dividen Pembayaran Rasio Konstan.

b. Kebijakan Dividen Teratur.

c. Kebijakan Dividen Rendah Teratur dan Ditambah Ekstra

$$
\mathrm{DPR}=\frac{\text { Dividend Per Share (DPS) }}{\text { Earning Per Share(EPS) }} \times 100 \%
$$

\section{KERANGKA KONSEP DAN HIPOTESIS PENELITIAN \\ Kerangka Konsep}

Gambar 3.1.

Kerangka Konsep Penelitian

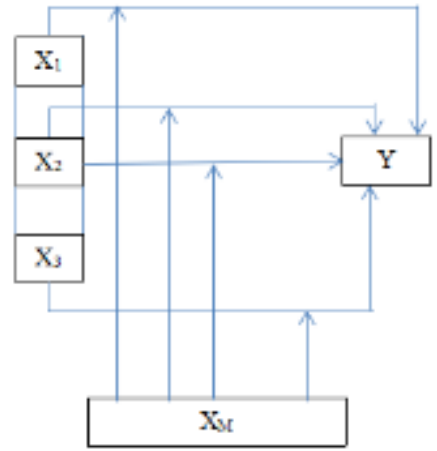

Keterangan

$\mathrm{Y}=$ Nilai Perusahaan diproxykan melalui Price Earning Ratio (PER)

$\mathrm{X}_{1}=$ Struktur Modal diproxykan melalui Debt To EquityRatio (DER)

$\mathrm{X}_{2}=$ Profitabilitas diproxykan melalui Return On Assets (ROA)

$\mathrm{X}_{3}=$ Ukuran Perusahaan diproxykan melalui Firm Size.

$\mathrm{Xm}=$ Kebijakan Dividen diproxykan melalui Dividend Payout Ratio (DPR)

\section{Hipotesis Penelitian}

Berdasarkan rumusan masalah dan tujuan penelitian maka dapat diajukan hipotesis penelitian sebagai berikut:

$\mathrm{H}_{1}$ : Secara Partial, Terdapat Pengaruh DER Terhadap PER.

$\mathrm{H}_{2}$ : Secara Partial, Terdapat Pengaruh ROA Terhadap PER.

$\mathrm{H}_{3}$ : Secara Partial, Terdapat Pengaruh Firm Size. Terhadap PER.
$\mathrm{H}_{4}$ : Secara Simultant, Terdapat Pengaruh DER, ROA, dan Firm Size Terhadap PER.

$\mathrm{H}_{5}$ : Pada Tingkat Signifikansi 0.05, DPR mampu memoderasi Pengaruh DER Terhadap PER.

$\mathrm{H}_{6}$ : Pada Tingkat Signifikansi 0.05, DPR mampu memoderasi Pengaruh ROA) Terhadap PER.

$\mathrm{H}_{7}$ : Pada Tingkat Signifikansi 0.05, DPR mampu memoderasi Pengaruh Firm Size. Terhadap PER.

$\mathrm{H}_{8}$ : Pada Tingkat Signifikansi 0.05, DPR mampu memoderasi Pengaruh secara simultant DER, ROA, dan Firm Size Terhadap PER.

Dari hipotesis hipotesis tersebut di atas, maka dapat disusun Hipotesis Statistik sebagai berikut:

$\mathrm{Ho}_{1} \rho=0$ Tidak Terdapat Pengaruh DER Terhadap PER.

$\mathrm{Ha}_{1} \quad \rho \neq 0$ Terdapat Pengaruh DER Terhadap PER.

$\mathrm{Ho}_{2} \rho=0$ Tidak Terdapat Pengaruh ROA Terhadap PER.

$\mathrm{Ha}_{2} \quad \rho \neq 0$ Terdapat Pengaruh ROA Terhadap PER.

$\mathrm{Ho}_{3} \rho=0$ Tidak Terdapat Pengaruh Firm Size. Terhadap PER.

$\mathrm{Ha}_{3} \quad \rho \neq 0$ Terdapat Pengaruh Firm Size. Terhadap PER.

$\mathrm{Ho}_{4} \rho=0$ Tidak Terdapat Pengaruh DER, ROA dan Firm Size Terhadap PER.

$\mathrm{Ha}_{4} \quad \rho \neq 0$ Terdapat Pengaruh Pengaruh DER, ROA dan Firm Size Terhadap PER

$\mathrm{Ho}_{5} \rho=0$ DPR tidak mampu memoderasi Pengaruh DER Terhadap PER.

$\mathrm{Ha}_{5} \rho \neq 0$ DPR mampu memoderasi Pengaruh DER Terhadap PER.

Ho6 $\rho=0$ DPR tidak mampu memoderasi Pengaruh ROA Terhadap PER. 
$\mathrm{Ha}_{6} \quad \rho \neq 0$ DPR mampu memoderasi Pengaruh ROA Terhadap PER.

$\mathrm{Ho}_{7} \rho=0$ DPR tidak mampu memoderasi Pengaruh Firm Size. Terhadap PER.

$\mathrm{Ha}_{7} \quad \rho \neq 0$ DPR mampu memoderasi Pengaruh Firm Size. Terhadap PER.

Ho8 $\rho=0$ DPR tidak mampu memoderasi Pengaruh secara simultant DER, ROA dan Firm Size Terhadap PER.

Has $\quad \rho \neq 0$ DPR mampu memoderasi Pengaruh secara simultant DER, ROA dan Firm Size Terhadap PER.

\section{METODE PENELITIAN \\ Jenis Penelitian}

Jenis penelitian ini adalah penelitian dokumentasi karena sumber data yang digunakan adalah secondary data dengan mengakses : www.idx.co.id.

Pendekatan penelitian yang digunakan adalah Positivistic Quantitative (Sugiyono, 2007: 15).

\section{Populasi Dan Teknik Penarikan Sample}

Sugiyono (2008: 121) di dalam bukunya yang berjudul Metode Penelitian Pendidikan, menjelaskan bahwa yang dimaksud dengan populasi adalah wilayah generalisasi yang terdiri dari objek atau subjek yang mempunyai kualitas dan karakteristik tertentu yang ditetapkan oleh peneliti untuk dipelajari dan kemudian ditarik kesimpulannya.

Peneliti harus menentukan populasi sasaran (Istijanto, 2009: 117). Ada pun yang menjadi populasi sasaran dalam penelitian ini adalah Emiten pada Sector Manufacture dengan Sub Sector Consumer Goodslisting di Bursa Efek Indonesia sebanyak 38 (Tiga Puluh Delapan) emiten yang ada dalam Tabel 4.1 di bawah ini

Tabel 4.1.

Populasi Penelitian

( $\mathrm{N}=38$ Emiten Consumer Goods)

\begin{tabular}{|l:l:l|}
\hline No & CODE & SUB SECTOR \\
\hline 1 & ADES & Makanan dan Minuman \\
\hline
\end{tabular}

\begin{tabular}{|c|c|c|}
\hline 2 & AISA & Makanan dan Minuman \\
\hline 3 & ALTO & Makanan dan Minuman \\
\hline 4 & CEKA & Makanan dan Minuman \\
\hline 5 & DAVO & Makanan dan Minuman \\
\hline 6 & DLTA & Makanan dan Minuman \\
\hline 7 & ICBP & Makanan dan Minuman \\
\hline 8 & INDF & Makanan dan Minuman \\
\hline 9 & MLBI & Makanan dan Minuman \\
\hline 10 & MYOR & Makanan dan Minuman \\
\hline 11 & PSDN & Makanan dan Minuman \\
\hline 12 & ROTI & Makanan dan Minuman \\
\hline 13 & SKBM & Makanan dan Minuman \\
\hline 14 & SKLT & Makanan dan Minuman \\
\hline 15 & STTP & Makanan dan Minuman \\
\hline 16 & ULTJ & Makanan dan Minuman \\
\hline 17 & GGRM & Rokok \\
\hline 18 & HMSP & Rokok \\
\hline 19 & RMBA & Rokok \\
\hline 20 & WIIM & Rokok \\
\hline 21 & DVLA & Farmasi \\
\hline 22 & INAF & Farmasi \\
\hline 23 & KAEF & Farmasi \\
\hline 24 & KLBF & Farmasi \\
\hline 25 & MERK & Farmasi \\
\hline 26 & PYFA & Farmasi \\
\hline 27 & SCPI & Farmasi \\
\hline 28 & SIDO & Farmasi \\
\hline 29 & SQBB & Farmasi \\
\hline 30 & SQBI & Farmasi \\
\hline 31 & TSPC & Farmasi \\
\hline 32 & MBTO & Cosmetics and Household \\
\hline 33 & MRAT & Cosmetics and Household \\
\hline 34 & TCID & Cosmetics and Household \\
\hline 35 & UNVR & Cosmetics and Household \\
\hline 36 & KDSI & Houseware \\
\hline 37 & KICI & Houseware \\
\hline 38 & LMPI & Houseware \\
\hline
\end{tabular}

Sumber: www.idx.co.id

Purposive sampling adalah teknik penentuan sampel dengan kriteria kriteria yang mendasari pertimbangan tertentu yang telah disinggung pada bahasan terdahulu. sehingga data yang diperoleh lenih 
representative dengan melakukan proses penelitian yang kompeten dibidangnya."

Adapun criteria-criteria yang digunakan untuk Purposive Sampling adalah:

1. Laporan Keuangan Tahunan dalam bentuk IDR

2. Durasi Waktu Tahun Fiskal 2013, 2014, 2015, 2016 dan 2017.

3. Emiten Sector Manufakture dengan Sub Sector Consumer Goods yang berbayar Dividend selama periode Tahun Fiskal 2013, 2014, 2015, 2016 dan 2017.

4. Emiten Sector Manufacture dengan Sub Sector Consumer Goods yang profit selama periode Tahun Fiskal 2013, 2014, 2015, 2016 dan 2017.

5. Secara berturut turut Masuk ke Listing LQ 45 selama Tahun Fiskal 2013, 2014, 2015, 2016 dan 2017 atau selama sepuluh semester tanpa dikeluarkan dari Listing LQ 45 di Bursa Efek Indonesia

Tabel 4.2.

Sampel Sasaran Penelitian

( $\mathrm{n}=4$ emiten)

\begin{tabular}{|c|c|c|c|c|}
\hline No & CODE & & EMITEN & \\
\hline 1 & $\begin{array}{l}\text { GGR } \\
\text { M }\end{array}$ & $\begin{array}{l}\mathrm{P} \\
\mathrm{T}\end{array}$ & Gudang Garam & $\begin{array}{l}\mathrm{Tb} \\
\mathrm{k}\end{array}$ \\
\hline 2 & INDF & $\begin{array}{l}\mathrm{P} \\
\mathrm{T}\end{array}$ & $\begin{array}{l}\text { Indofood } \\
\text { Makmur }\end{array}$ & $\begin{array}{l}\mathrm{Tb} \\
\mathrm{k}\end{array}$ \\
\hline 3 & KLBF & $\begin{array}{l}\mathrm{P} \\
\mathrm{T}\end{array}$ & Kalbe Farma & $\begin{array}{l}\mathrm{Tb} \\
\mathrm{k}\end{array}$ \\
\hline 4 & UNVR & $\begin{array}{l}\mathrm{P} \\
\mathrm{T}\end{array}$ & Unilever Indonesia & $\begin{array}{l}\mathrm{Tb} \\
\mathrm{k}\end{array}$ \\
\hline
\end{tabular}

\section{Instrument Alat Pengumpulan Data}

Sumber data penelitian ini adalah secondary data. Sedangkan teknik pengumpulan data atau alat pengumpulan data penelitian ini adalah: Metode Dokumentasi berupa Laporan Keuangan Korporasi Sector ManufactureSub Sector Consumer Goodslisting di Bursa Efek Indonesia : www.idx.co.id.

\section{Uji Persyaratan Analisis atau Uji Asumsi Regresi atau Uji Asumsi Klasik}

\section{Uji Normalitas Data}

Untuk menguji normalitas data diajukan hipotesis sebagai berikut:

\section{a. Dari perspektif Kolmogorov-Smirnov $\mathbf{Z}$ ( $\left.\mathbf{Z}_{\text {HITUNG }}\right)$}

Imam Ghozali (2007: 114) menjelaskan dengan cara membandingkan perolehan nilai $\mathrm{Z}$ hitung setiap indikator pada setiap variabel yang diteliti. Adapun yang menjadi dasar pengambilan keputusan sebagai berikut:

1) Jika perolehan nilai KolmogorovSmirnov Z $\left(Z_{\text {HITUNG }}\right)>1.97$ maka Ho ditolak sebaliknya Ha diterima. Artinya, data berasal dari populasi yang tidak berdistribusi normal.

2) Jika perolehan nilai KolmogorovSmirnov $\mathrm{Z}\left(\mathrm{Z}_{\text {HITUNG }}\right)<1.97$, maka Ho diterima sebaliknya Ha ditolak. Artinya, data berasal dari populasi yang berdistribusi normal.

b. Dari perspektif asymptotic significancy (2-tailed)

R. Gunawan Sudarmanto (2005: 109) menjelaskan dengan cara membandingkan tingkat $\alpha$ (yang kita tetapkan sebelumnya apakah tingkat akurasi $99 \%$ berarti $\alpha 0.01$, atau tingkat akurasi $95 \%$ berarti $\alpha \quad 0.05$ atau tingkat akurasi $90 \%$ berarti $\alpha 0.10$ ). Adapun yang menjadi dasar pengambilan keputusan sebagai berikut:

1) Jika nilai asymptotic significancy (2-tailed) $<\alpha \quad 0.05$. Ho ditolak sebaliknya Ha diterima. Artinya, data berasal dari populasi yang tidak berdistribusi normal.

2) Jika nilai asymptotic significancy (2-tailed) $>\alpha \quad 0.05$, Ho diterima sebaliknya Ha ditolak. Artinya, data berasal dari populasi yang berdistribusi normal.

Setelah melalui proses pengolahan data dengan menggunakan Aplikasi Program SPSS v 25 New Release For Windows, maka diperoleh hasil Uji Normalitas Data yang ditampilkan melalui Tabel 4.3 di bawah ini

Tabel 4.3

Hasil Uji Normalitas Data

(Obeservasi $=20)$

One-Sample Kolmogorov-Smirnov Test

\begin{tabular}{|c|c|c|}
\hline & & $\begin{array}{l}\text { Unstandardized } \\
\text { Residual }\end{array}$ \\
\hline $\begin{array}{l}\text { N } \\
\text { Normal Parameters }{ }^{\mathrm{a}, \mathrm{b}} \\
\text { Most Extreme Differences } \\
\text { Test Statistic } \\
\text { Asymp. Sig. (2-tailed) }\end{array}$ & $\begin{array}{l}\text { Mean } \\
\text { Std. Deviation } \\
\text { Absolute } \\
\text { Positive } \\
\text { Negative }\end{array}$ & $\begin{array}{l}20 \\
4.3769000 \\
.58940000 \\
.136 \\
.136 \\
-.091 \\
.136 \\
.088^{\mathrm{c}} \\
\end{array}$ \\
\hline \multicolumn{3}{|l|}{$\begin{array}{l}\text { a. Test distribution is Normal. } \\
\text { b. Calculated from data. }\end{array}$} \\
\hline 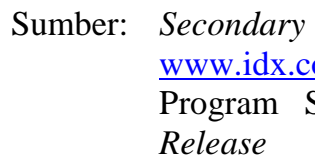 & $\begin{array}{c}\text { Data } \\
\text { o.id diolah d } \\
\text { SPSS v } 25\end{array}$ & $\begin{array}{c}\text { pada } \\
\text { engan Aplikasi } \\
\text { For Windows }\end{array}$ \\
\hline
\end{tabular}


Dengan mencermati Tabel 4.3 di atas maka dapat ditarik analisis sebagai berikut:

a. Dari perspektif Kolmogorov-Smirnov $\mathbf{Z}$ ( $\left.\mathbf{Z}_{\text {HITUNG }}\right)$

Diperoleh nilai 0.136 di mana lebih kecil ketimbang 1.97, maka Ho diterima sebaliknya Ha ditolak. Artinya, data berasal dari populasi yang berdistribusi normal.

b. Dari perspektif asymptotic significancy (2-tailed)

Diperoleh nilai 0.088 di mana lebih besar ketimbang 0.05 maka Ho diterima sebaliknya Ha ditolak. Artinya, data

\begin{tabular}{|c|c|c|c|c|c|c|c|}
\hline \multirow[b]{2}{*}{ Model } & \multicolumn{2}{|c|}{$\begin{array}{l}\text { Unstandardized } \\
\text { Coefficients }\end{array}$} & \multirow{2}{*}{$\begin{array}{l}\text { Standardized } \\
\text { Coefficients } \\
\text { Beta }\end{array}$} & \multirow[b]{2}{*}{$\mathrm{t}$} & \multirow[b]{2}{*}{ Sig. } & \multicolumn{2}{|c|}{$\begin{array}{l}\text { Collinearity } \\
\text { Statistics }\end{array}$} \\
\hline & B & Std. Error & & & & Tolerance & $\begin{array}{l}\mathrm{VIF} \\
\end{array}$ \\
\hline (Constant) & .335 & .151 & & 2.074 & .026 & & \\
\hline DER & .971 & .375 & .756 & $\begin{array}{l}6.740 \\
2.375\end{array}$ & $\begin{array}{l}.015 \\
029\end{array}$ & .428 & $\begin{array}{l}2.336 \\
1.66\end{array}$ \\
\hline ROA & .412 & .357 & .377 & 2.375 & .029 & .858 & 1.100 \\
\hline Firm Size & .323 & .202 & .345 & 2.141 & .048 & .881 & 1.135 \\
\hline DPR & .985 & .270 & .890 & 11.367 & .004 & .208 & 4.800 \\
\hline
\end{tabular}

2. Uji multikolinearitas data

R. Gunawan Sudarmanto (2005: 136-137) menjelaskan bahwa yang dimaksud dengan uji multikolinearitas adalah untuk membuktikan ada tidaknya hubungan yang linear antara variabel bebas (independent variable) satu dengan variabel bebas (independent variable) lainnya. Dalam multiple regression analysis, akan terdapat dua atau lebih variable bebas (independent variable) yang diduga akan mempengaruhi variabel terikat (dependent variable).

Adanya hubungan yang linear antar variabel bebas (independent variable) akan menimbulkan kesulitan dalam memisahkan pengaruh masing-masing variabel bebas (independent variable) terhadap variabel terikat (dependent variable).

Lebih mendalam lagi, R. Gunawan Sudarmanto (2005: 138) menjelaskan bahwa adapun hipotesis yang akan diuji untuk membuktikan ada tidaknya multikolinearitas antar variabel bebas (independent variable) dinyatakan sebagai berikut:

Ho: tidak terjadi hubungan antar variabel bebas (independent variable)

Ha: terjadi hubungan antar variabel bebas (independent variable).

Untuk mendapatkan hasil pengujian multikolinearitas data, maka dapat digunakan nilai VIF. Adapun yang menjadi dasar pengambilan keputusan sebagai berikut:

a. Jika nilai $\mathrm{VIF}_{\text {HItUNG }}<5$ atau 10. mengindikasikan bahwa Ho diterima, sebaliknya Ha ditolak. Berarti, tidak terjadi multikolinieritas. Sedangkan dari nilai Tolerance > 0.20 atau 0.10 mengindikasikan bahwa Ho diterima, sebaliknya Ha ditolak. Berarti, tidak terjadi multikolinieritas.

b. Jika nilai $\operatorname{VIF}_{\text {HITUNG }}>5$ atau 10 , mengindikasikan bahwa $\mathrm{Ha}$ diterima, sebaliknya Ho ditolak. Berarti terjadi multikolinieritasserius. Sedangkan dari nilai Tolerance $<0.20$ atau 0.10 mengindikasikan bahwa $\mathrm{Ha}$ diterima, sebaliknya Ho ditolak. Berarti terjadi multikolinieritasserius.

Tabel 4.4.

Hasil Uji Multikolinearitas Data

(Observasi $=20)$

Sumber: Secondary Data pada URL www.idx.co.id diolah dengan Aplikasi Program SPSS v 25 For Windows Release

Dengan mencermati Tabel 4.4 di atas maka dapat ditarik analisis sebagai berikut:

a. Dari perspektif nilai Tolerance, setiap variable bebas yang diteliti memiliki nilai Tolerance lebih besar ketimbang 0.20 atau 0.10 sehingga mengindikasikan bahwa Ho diterima, sebaliknya $\mathrm{Ha}$ ditolak. Berarti, tidak terjadi multikolinieritas.

b. Dari perspektif nilai $\mathbf{V I F}_{\text {HITUNG, setiap }}$ variable bebas yang diteliti memiliki nilai $\mathrm{VIF}_{\text {HITUNG }}$ lebih kecil ketimbang 5 atau 10 sehingga mengindikasikan bahwa Ho diterima, sebaliknya $\mathrm{Ha}$ ditolak. Berarti, tidak terjadi multikolinieritas.

3. Uji Heteroskedastisitas Data dengan Glejser

R. Gunawan Sudarmanto (2005: 138) menjelaskan bahwa uji heteroskedastisitas digunakan untuk mengetahui adanya ketidaksamaan varian dari residual untuk semua pengamatan pada model regresi. Prasyarat yang harus terpenuhi dalam model regresi adalah tidak adanya gejala heteroskedastisitas, Dengan demikian, data yang diharapkan bersifat data populasi yang homogen. 
Ada beberapa metode pengujian yang bisa digunakan untuk uji heteroskedastisitas data antara lain adalah: a. Uji Park; b. Uji Glesjer; c. Dengan melihat dan mencermati pola grafik regresi; dan d. Uji koefisien korelasi Spearman.

Dalam konteks penelitian ini, yang digunakan untuk uji heteroskedastisitas data adalah dengan melihat dan mencermati hasil uji Glesjer. Adapun hipotesis yang akan diuji untuk membuktikan ada tidaknya Heteroskedastisitas dinyatakan sebagai berikut:

Ho: Tidak Terjadi Heteroskedastisitas Data

Ha: Terjadi Heteroskedastisitas Data

Pengambilan keputusan:

a. Jika nilai Asymptotic Significancy< 0.05 maka Ho ditolak sebaliknya Ha diterima. Berarti, telah terjadi heteroskedastisitas data.

b. Jika nilai Asymptotic Significancy $>0.05$ maka Ho diterima sebaliknya Ha ditolak. Berarti, tidak terjadi heteroskedastisitas data.

Setelah melalui proses pengolahan data dengan menggunakan Aplikasi Program SPSS v 25 New Release For Windows, maka diperoleh hasil Uji Heterokedastisitas Data yang ditampilkan melalui Tabel 4.5 di bawah ini.

Tabel 4.5. Hasil Uji Heterokedastisitas Data

$($ Observasi $=20)$

Sumber: Secondary Data pada URL www.idx.co.id diolah dengan Aplikasi Program SPSS v 25 For Windows Release

Dengan mencermati Tabel 4.5 di atas maka dapat ditarik analisis bahwa setiap variabel bebas yang diteliti memiliki nilai Asymptotic Significancy lebih besar ketimbang 0.05 sehingga mengindikasikan Ho diterima sebaliknya Ha ditolak. Berarti, tidak terjadi heteroskedastisitas data. Oleh karena itu, data yang ada telah memenuhi persyaratan uji heterokedastisitas data sebagai salah satu komponen dari Uji Persyaratan Analisis atau Uji Asumsi Regresi atau Uji Asumsi Klasik.

\section{Uji Autokorelasi}

R. Gunawan Sudarmanto (2011: 56) menjelaskan bahwa uji autokorelasi bertujuan untuk menguji apakah dalam suatu model regresi linear ada korelasi antara kesalahan pengganggu pada suatu periode dengan periode sebelumnya. Masalah autokorelasi sering ditemukan pada data time series karena gangguan pada suatu perusahaan cenderung mempengaruhi perusahaan yang sama pada periode berikutnya. Sedangkan pada data cross section, masalah autokorelasi relatif jarang terjadi karena "gangguan" pada observasi yang berbeda berasal dari perusahaan yang berbeda.

Penelitian ini menggunakan data time series dan data cross section yang dikombinasikan melalui model panel data, sehingga dimungkinkan tidak terjadi masalah autokorelasi. Untuk mengetahui apakah terjadi masalah autokorelasi maka dilakukan uji Durbin-Watson dengan ketentuan yang dituangkan pada Tabel 4.6 di bawah ini.

Sumber: Imam Ghozali. 2007. Aplikasi Analisis Multivariate. Semarang. Badan Penerbit Universitas Diponegoro. hlm

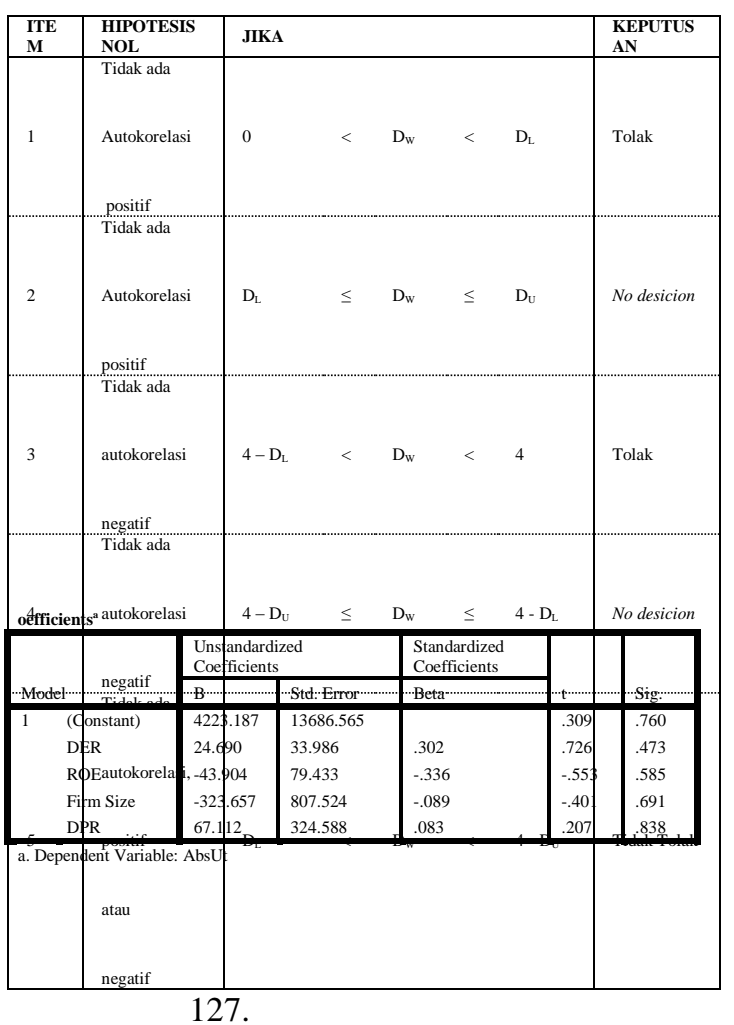

Adapun yang menjadi dasar pengambilan keputusan untuk mendapatkan Durbin Watson Tabel pada $D_{L}$ (Durbin Watson Low) dan $\mathrm{D}_{\mathrm{U}}$ (Durbin Watson Upper) pada $\alpha 0.05(\mathrm{n}, \mathrm{k})$ sebagai berikut:

$\mathrm{N}=$ jumlah observasi 
$\mathrm{k} \quad=$ jumlah variable bebas (independent variable).

\section{Teknik Analisis Data}

1. Descriptive Statistic Analysis

Analisis deskriptif adalah statistik yang digunakan untuk menganalisa data dengan cara mendeskripsikan atau menggambarkan data yang telah terkumpul sebagaimana adanya tanpa bermaksud membuat kesimpulan yang berlaku untuk umum atau generalisasi. Dalam penelitian ini, analisis deskripsi meliputi: a. Ukuran Pemusatan terdiri dari: mean, median, modus; dan

b. Ukuran Penyebaran melalui standard deviation atau simpang baku.

\section{Partial Regression Analysis Model}

Adapun teknik analisis data yang diterapkan pada penelitian ini adalah Ordinary Least Square (Residu Kuadrat Terkecil) pada Partial Regression Analysis Model sehingga memunculkan fungsi persamaan regresi berganda (Multiple Regression Analysis Model) sebagai berikut:

$f(Y)=\beta_{0}+\beta X+\varepsilon$ di mana

$\mathrm{Y}=$ Subjek variable yang diproyeksi

$\mathrm{X}=$ variabel bebas yang mempunyai nilai tertentu untuk diprediksikan sehingga berperan fungsi sebagai predictor

$\beta_{0}=$ Intercept atau constanta harga $\hat{\mathrm{Y}}$ jika $\mathrm{X}=0$ dengan formulasi sebagai berikut:

$$
\beta_{0}=\frac{\left(\sum \mathrm{Y}\right)\left(\sum \mathrm{X}^{2}\right)-\left(\sum \mathrm{X}\right)\left(\sum \mathrm{XY}\right)}{\mathrm{n} \sum \mathrm{X}^{2}-\left(\sum \mathrm{X}\right)^{2}}
$$

$\beta=$ Slop atau regression coefficient atau nilai arah sebagai penentu ramalan (prediksi) yang menunjukkan ada tidaknya peningkatan (+) atau penurunan (-) nilai perolehan variable $\hat{Y}$ yang dipengaruhi besaran nilai Variabel X. Dalam hal ini, perolehan nilai slop atau regession coefficient merupakan nilai kelipatan bagi $\mathrm{f}(\mathrm{Y})$. Adapun formulasi slop atau regression coefficient sebagai berikut:

$\beta=\frac{\mathrm{n}\left(\sum \mathrm{XY}\right)-\left(\sum \mathrm{X}\right)\left(\sum \mathrm{Y}\right)}{\mathrm{n}\left(\sum \mathrm{X}^{2}\right)-\left(\sum \mathrm{X}\right)^{2}}$

$\varepsilon=$ Epsilon atau residual. Untuk mendapatkan nilai épsilon atau residual menggunakan rumus (Ghozali,

$$
\begin{aligned}
& \text { 2007, } 127) \quad \text { sebagai berikut: } \\
& \varepsilon=\sqrt{\left(1-\mathrm{R}^{2}\right)}
\end{aligned}
$$

\section{Multiple Regression Analysis Model}

Multiple Regression Analysis Model s memunculkan fungsi persamaan regresi berganda (Multiple Regression Analysis Model) sebagai berikut:

$f(Y)=\beta_{0}+\beta_{1} X_{1}+\beta_{2} X_{2}+\beta_{3} X_{3}+\varepsilon$ di mana

$\mathrm{Y} \quad=$ Subjek variable yang diproyeksi bebas yang
variabel

$\mathrm{X}_{1}, \mathrm{X}_{2}, \mathrm{X}_{3}=$ variabel bebas yang untuk diprediksikan sehingga berperan fungsi sebagai predictor

$\beta_{0}=$ Intercept atau constanta harga $\hat{Y}$ jika $X=0$ dengan formulasi sebagai berikut:

$\beta_{0}=\frac{\left(\sum Y\right)\left(\sum X^{2}\right)-\left(\sum X\right)\left(\sum X Y\right)}{n \sum X^{2}-\left(\sum X\right)^{2}}$

$\beta_{1}, \beta_{2}, \beta_{3}, \quad=$ Slop atau regression coefficient atau nilai arah sebagai penentu ramalan (prediksi) yang menunjukkan ada tidaknya peningkatan (+) atau penurunan (-) nilai perolehan variable $\hat{\mathrm{Y}}$ yang dipengaruhi besaran nilai Variabel X. Dalam hal ini, perolehan nilai slop atau regession coefficient merupakan nilai kelipatan bagi $\mathrm{f}(\mathrm{Y})$. Adapun formulasi slop atau regression coefficient sebagai berikut: $\beta=\frac{\mathrm{n}\left(\sum \mathrm{XY}\right)-\left(\sum \mathrm{X}\right)\left(\sum \mathrm{Y}\right)}{\mathrm{n}\left(\sum \mathrm{X}^{2}\right)-\left(\sum \mathrm{X}\right)^{2}}$

$\varepsilon=$ Epsilon atau residual. Untuk mendapatkan nilai épsilon atau residual menggunakan rumus (Ghozali, 2007, 127) sebagai berikut: $\varepsilon=\sqrt{\left(1-\mathrm{R}^{2}\right)}$

\section{Pengujian Hipotesis}

Dengan mencermati hipotesis penelitian, maka melahirkan pengujian hipotesis 
penelitian secara partial dan secara simultant.

\section{a. Uji t}

Sugiyono (2007: 277) menjelaskan bahwa khusus untuk partialregression analysis model pengujian hipotesis yang digunakan peneliti adalah uji $\mathrm{t}$ ( $\mathrm{t}$ test) sebagai model pengujian hipotesis dengan cara membandingkan nilai $t_{\text {HITUNG }}$ dengan $\mathrm{t}_{\mathrm{TABEL}}$ Untuk mendapatkan nilai thitung digunakan rumus sebagai berikut:

$\mathrm{t}_{\text {HITUNG }}=\mathrm{r} \sqrt{\frac{\mathrm{n}-2}{1-\mathrm{r}^{2}}}$ di mana

$\mathrm{n} \quad=$ jumlah sampel

$\mathrm{r} \quad=$ koefisien korelasi

$\mathrm{r}^{2} \quad=$ korelasi determinasi (nilai besaran rsquare)

Adapun yang menjadi dasar pengambilan keputusan sebagai berikut:

1) Jika $t_{\text {HITUNG }}<t_{\text {TABEL }}$ pada $1 / 2 \alpha(0.05)$ atau 2-Tailed. maka Ho diterima dan Ha ditolak, artinya tidak ada Pengaruh antara variabel $\mathrm{X}$ dan variabel Y.

2) Jika $t_{\text {HITUNG }}>t_{\text {TABEL }}$ pada $1 / 2 \alpha(0.05)$ atau 2-Tailed maka Ho ditolak dan Ha diterima, artinya ada Pengaruh antara variabel $\mathrm{X}$ dan variabel $\mathrm{Y}$.

Sedangkan perolehan nilai asymptotic significancy (2-tailed) bertujuan untuk melihat siginifikan tidaknya koefisiensi korelasi secara parsial. Dalam hal ini berlaku (Sendjojo 2011: 107) sebagai berikut:

1) Jika perolehan nilai asympotetic significancy $<0.05$. maka koefisiensi korelasi ( $\rho)$ secara partial bersifat signifikan

2) Jika perolehan nilai asympotetic significancy > 0.05 . maka koefisiensi korelasi $(\rho)$ secara partial bersifat tidak signifikan.

\section{b.Uji F}

Suharsimi Arikunto (2010: 21) menjelaskan bahwa uji beda atau uji Fatau anova testsebagai model pengujian hipotesisdengan cara membandingkan nilai $\mathrm{F}_{\text {hitung }}$ dengan $\mathrm{F}_{\text {tabel. }}$. Untuk mendapatkan nilai $F_{\text {hitung digunakan }}$ formulasi sebagai berikut:

$$
\mathrm{F}_{\text {HITUNG }}=\frac{\frac{\mathrm{r}^{2}}{\mathrm{k}}}{\frac{\left(1-\mathrm{r}^{2}\right)}{\mathrm{n}-\mathrm{k}-1}} \text { di mana }
$$

$\mathrm{r}=$ coefficient of multiple correlation

$\mathrm{k}=$ banyaknya variabel bebas (independent variable)

$\mathrm{n}$ = banyaknya sampel penelitian

Adapun yang menjadi dasar dalam pengambilan keputusan sebagai berikut:

a. Jika $F_{\text {hitung }}<F_{\text {tabel }}$ maka Ho diterima dan Ha ditolak, artinya tidak terdapat pengaruh variabel $X_{1}, X_{2}, \ldots$ dan $X_{n}$ secara simultant terhadap variabel $\mathrm{Y}$.

b. Jika $F_{\text {hitung }}>F_{\text {tabel }}$ maka Ho ditolak dan Ha diterima, artinya terdapat pengaruh $\mathrm{X}_{1}, \mathrm{X}_{2}, \ldots$ dan $\mathrm{X}_{\mathrm{n}}$ secara simultant terhadap variabel $\mathrm{Y}$.

berlaku (Sandjojo 2011: 107) sebagai berikut:

1) Jika perolehan nilai asympotetic significancy < 0.05. maka koefisiensi korelasi $(\rho)$ secara simultant bersifat signifikan

2) Jika perolehan nilai asympotetic significancy $<0.05$. maka koefisiensi korelasi ( $\rho)$ secara simultant bersifat signifikan.

\section{Moderated Regression Analysis Model}

Menurut Ghozali (2011: 223) Uji interaksi atau sering disebut dengan Moderated Regression Analysis (MRA) merupakan aplikasi khusus regresi berganda linier dimana dalam persamaan regresinya mengandung unsur interaksi (perkalian dua atau lebih variabel independen). Adapun Moderating Regression Analysis (MRA) dinyatakan dalam dua bentuk persamaan sebagai berikut:

a. Secara Partial menimbulkan dua persamaan sebagai berikut:

Persamaan I $Y=\beta_{0}+\beta X+\varepsilon$

Untuk Tingkat Signifikansi 0.05, DPR mampu memoderasi Pengaruh DER Terhadap PER memunculkan Persamaan II

$\mathrm{Y}=\beta_{0}+\beta_{1} \mathrm{X}_{1}+\beta_{4} \mathrm{X}_{\mathrm{m}}+\beta_{5}\left[\mathrm{X}_{1} * \mathrm{Xm}\right]+\varepsilon$

Keterangan:

$\begin{array}{ll}\mathrm{Y} & =\text { PER } \\ \mathrm{X}_{1} & =\text { DER }\end{array}$ 


$$
\begin{aligned}
\mathrm{Xm} & =\text { DPR } \\
\mathrm{X}_{1} * \mathrm{Xm} & =\text { Interaksi antara DER dengan } \\
& \\
\varepsilon & =\text { DPR } \\
& =\text { Residual }
\end{aligned}
$$

Untuk Tingkat Signifikansi 0.05, DPR mampu memoderasi Pengaruh ROA Terhadap PER memunculkan Persamaan II

$Y=\beta_{0}+\beta_{2} X_{2}+\beta_{4} X_{m}+\beta_{5}\left[X_{2} * X m\right]+\varepsilon$

Keterangan:

$$
\begin{aligned}
& \mathrm{Y} \quad=\text { PER } \\
& \mathrm{X}_{2} \quad=\mathrm{ROA} \\
& \mathrm{Xm} \quad=\text { DPR } \\
& \mathrm{X}_{2} * \mathrm{Xm}=\text { Interaksi antara ROA dengan } \\
& \text { DPR. } \\
& \varepsilon=\text { Residual } \\
& \mathrm{Y} \quad=\text { PER } \\
& \mathrm{X}_{3} \quad=\text { Firm Size } \\
& \mathrm{Xm} \quad=\mathrm{DPR} \\
& \mathrm{X}_{3} * \mathrm{Xm}=\text { Interaksi antara Firm Size } \\
& \varepsilon \quad=\text { Residual }
\end{aligned}
$$

b. Secara Simultant menimbulkan dua persamaan sebagai berikut:

Persamaan I $Y=\beta_{0}+\beta_{1} X_{1}+\beta_{2} X_{2}+\beta_{3} X_{3}+\varepsilon$

Untuk Tingkat Signifikansi 0.05, DPR mampu memoderasi Pengaruh DER, ROA, dan Firm Size Terhadap PER memunculkan Persamaan II

$$
\begin{aligned}
& \mathrm{Y}=\beta_{0}+\beta_{1} \mathrm{X}_{1}+\beta_{2} \mathrm{X}_{2}+\beta_{3} \mathrm{X}_{3}+\beta_{4} \mathrm{X}_{\mathrm{m}}+\beta_{5}\left[\mathrm{X}_{1} * \mathrm{X}_{2} * \mathrm{X}_{3} * \mathrm{Xm}\right] \\
& +\varepsilon \\
& \text { Keterangan: } \\
& \mathrm{Y} \\
& \mathrm{X}_{1} \quad=\text { DER } \\
& \mathrm{X}_{2} \quad=\text { ROA } \\
& \mathrm{X}_{3} \quad=\text { Firm Size } \\
& \mathrm{Xm} \quad=\text { DPR } \\
& \mathrm{X}_{1} * \mathrm{X}_{2} * \mathrm{X}_{3} * \mathrm{Xm}=\text { Interaksi antara DER, } \\
& \text { ROA, Firm Size } \\
& \text { dengan DPR } \\
& \varepsilon \quad=\text { Residual }
\end{aligned}
$$

\section{ANALISIS DAN PEMBAHASAN \\ Analisis}

1. Statistic Descriptive
Tabel 5.1.

Statistic Descriptive

$($ Observasi $=4$ Emiten $\mathrm{x} 5$ variabel $)$

Statistics
\begin{tabular}{|ll|l|l|l|l|l|}
\hline & & & & & FIRM & \\
& & PER & DER & ROA & SIZE & DPR \\
\hline N & Valid & 20 & 20 & 20 & 20 & 20 \\
& Missing & 0 & 0 & 0 & 0 & 0 \\
Mean & & 26.8675 & .9918 & .1605 & 19.6988 & .9192 \\
Median & 25.0100 & .6685 & .0962 & 18.0626 & .7636 \\
Std. Deviation & 12.08786 & .83092 & .15269 & 6.91565 & .58908 \\
Minimum & 10.89 & .20 & .01 & 9.45 & .36 \\
Maximum & 50.65 & 2.65 & .45 & 30.44 & 1.98 \\
\hline
\end{tabular}

Sumber: Secondary Data, diproses dengan Aplikasi SPSS versi 25 for windows release.

Pada Tabel 5.1 di atas dapat dijelaskan bahwa:

a. Mean pada: 1) PER (Y) sebesar $26.875 ;$ 2) DER $\left(\mathrm{X}_{1}\right)$ sebesar 0.9918 ; 3) ROA $\left(\mathrm{X}_{2}\right)$ sebesar 0.1605 ; 4) Firm Size $\left(X_{3}\right)$ sebesar 19.6988; dan 5) DPR (Xm = Moderasi) sebesar 0.9192.

b. Median pada: 1) PER (Y) sebesar 25.0100; 2) DER $\left(\mathrm{X}_{1}\right)$ sebesar $0.6685 ; 3)$ ROA $\left(\mathrm{X}_{2}\right)$ sebesar 0.0962 ; 4) Firm Size $\left(\mathrm{X}_{3}\right)$ sebesar 18.0626; dan 5) DPR (Xm = Moderasi) sebesar 0.7636 .

c. Standard Deviation pada: 1) PER (Y) sebesar 12.08786; 2) DER $\left(\mathrm{X}_{1}\right)$ sebesar $0.83092 ; 3)$ ROA $\left(\mathrm{X}_{2}\right)$ sebesar $0.15269 ; 4)$ Firm Size $\left(X_{3}\right)$ sebesar 6.91565; dan 5) DPR (Xm = Moderasi) sebesar 0. 58908.

d. Minimum pada: 1) PER (Y) sebesar 10.89; 2) DER $\left(\mathrm{X}_{1}\right)$ sebesar $\left.0.20 ; 3\right)$

ROA $\left(\mathrm{X}_{2}\right)$ sebesar 0.01 ; 4) Firm Size $\left(\mathrm{X}_{3}\right)$ sebesar 9.45; dan 5) DPR (Xm = Moderasi) sebesar 0.36.

e. Maximum pada: 1) PER (Y) sebesar 50.65; 2) DER $\left(\mathrm{X}_{1}\right)$ sebesar $\left.2.65 ; 3\right)$ ROA $\left(\mathrm{X}_{2}\right)$ sebesar 0.45 ; 4) Firm Size $\left(\mathrm{X}_{3}\right)$ sebesar 30.44; dan 5) DPR $(\mathrm{Xm}=$ Moderasi) sebesar 1.98.

2. Partial Regression Analysis Sebelum Moderasi

Tabel 5.2.

Hasil Partial Regression Analysis Model

Sebelum Moderasi

$($ Observasi $=4$ emiten $\times 4$ variabel $)$

\begin{tabular}{|l|l|l|l:l:l:l|}
\hline VARIABEL & $\mathrm{R}$ & $\mathrm{R}^{2}$ & $\begin{array}{l}\text { thrtuN } \\
\mathrm{G}\end{array}$ & tTABEL & $\begin{array}{l}\text { Asymptotic } \\
\text { Significanc } \\
y\end{array}$ & 0.05 \\
\hline PER $(\mathrm{Y})$-DER $\left(\mathrm{X}_{1}\right)$ & 0.592 & 0.3508 & 3.119 & 1.79588 & 0.006 & 0.05 \\
\hline
\end{tabular}




\begin{tabular}{|c|c|c|c|c|c|c|}
\hline$-\mathrm{ROA}\left(\mathrm{X}_{2}\right)$ & 0.676 & 0.4576 & 3.897 & 1.79588 & 0.001 & 0.05 \\
\hline PER (Y) & 0.230 & 0.0529 & 1.940 & 1.79588 & 0.033 & \\
\hline
\end{tabular}

Sumber: Secondary Data, diproses dengan Aplikasi SPSS versi 25 for windows release.

Pada Tabel 5.2 di atas menggambarkan bahwa secara Partial:

a. Nilai korelasi (R) pada:

1) Pengaruh DER Terhadap PER sebesar 0.592 menunjukan kekuatan moderat (0.40-0.69) bersifat positif.

2) Pengaruh ROA Terhadap PER sebesar 0.676 menunjukkan kekuatan moderat (0.40-0.69) bersifat positif.

3) Pengaruh Firm Size Terhadap PER sebesar 0.230 menunjukkan kekuatan rendah (0.20-0.39) bersifat positif.

b. Nilai Korelasi Determinasi $\left(\mathrm{R}^{2}\right)$ pada:

1) Pengaruh DER Terhadap PER sebesar 0.3508 menunjukan $35.08 \%$ PER bergantung pada DER. Sedangkan $64.92 \%$ nya (100\%-35.08\%) PER dipengaruhi oleh Variabel Lain yang tidak diteliti pada penelitian ini.

2) Pengaruh ROA Terhadap PER sebesar 0.4576 menunjukkan 45.76\% PER bergantung pada ROA. Sedangkan $54.24 \%$ nya (100\%-45.76\%) PER dipengaruhi oleh Variabel Lain yang tidak diteliti pada penelitian ini.

3) Pengaruh Firm Size Terhadap PER sebesar 0.0529 menunjukkan $5.29 \%$ PER bergantung pada Firm Size. Sedangkan $94.71 \%$ nya $(100 \%$ $5.29 \%)$ PER dipengaruhi oleh Variabel Lain yang tidak diteliti pada penelitian ini.

c. Nilai thitung pada:

1) Pengaruh DER Terhadap PER sebesar 3.119 lebih besar ketimbang $\mathrm{t}_{\mathrm{TABEL}}$ sebesar 1.79588. Ini menunjukan $\mathrm{Ho}_{1}$ ditolak sedangkan $\mathrm{Ha}_{1}$ diterima. Artinya Terdapat Pengaruh DER Terhadap PER.

2) Pengaruh ROA Terhadap PER sebesar 3.897 lebih besar ketimbang $\mathrm{t}_{\mathrm{TABEL}}$ sebesar 1.79588. Ini menunjukan $\mathrm{Ho}_{2}$ ditolak sedangkan $\mathrm{Ha}_{2}$ diterima. Artinya Terdapat Pengaruh ROA Terhadap PER

3) Pengaruh Firm Size Terhadap PER sebesar 1.940 lebih besar ketimbang $\mathrm{t}_{\text {TABEL }}$ sebesar 1.79588. Ini menunjukan $\mathrm{Ho}_{3}$ ditolak sedangkan $\mathrm{Ha}_{3}$ diterima. Artinya Terdapat Pengaruh Firm Size Terhadap PER kendati besaran pengaruhnya rendah.

d. Nilai Asymptotic Significancypada:

1) Pengaruh DER Terhadap PER sebesar 0.006 lebih kecil ketimbang 0.05. Ini menunjukan $\mathrm{Ho}_{1}$ ditolak sedangkan $\mathrm{Ha}_{1}$ diterima. Artinya Terdapat Pengaruh DER Terhadap PER.

2) Pengaruh ROA Terhadap PER sebesar 0.001 lebih kecil ketimbang 0.05. Ini menunjukan $\mathrm{Ho}_{2}$ ditolak sedangkan $\mathrm{Ha}_{2}$ diterima. Artinya Terdapat Pengaruh ROA Terhadap PER.

3) Pengaruh Firm Size Terhadap PER sebesar 0.033 lebih kecil ketimbang 0.05. Ini menunjukan $\mathrm{Ho}_{3}$ ditolak sedangkan $\mathrm{Ha}_{3}$ diterima. Artinya Terdapat Pengaruh Firm Size Terhadap PER kendati besaran pengaruhnya rendah.

\section{Partial Regression AnalysisSetelah Moderasi}

Tabel 5.3.

Hasil Partial Regression Analysis Model Setelah Moderasi

(Observasi $=4$ emiten $\times 5$ variabel $)$

\begin{tabular}{|c|c|c|c|c|c|c|}
\hline VARIABEL & $\mathrm{R}$ & $\mathrm{R}^{2}$ & $\begin{array}{l}\text { thrTUN } \\
\text { G }\end{array}$ & tTABEL & $\begin{array}{l}\text { Asymptotic } \\
\text { Significanc } \\
y\end{array}$ & 0.05 \\
\hline$\overline{\operatorname{DER}}\left(\mathrm{X}_{1}\right)$ & 0.732 & 0.5361 & 1.813 & 1.75305 & 0.018957 & 0.05 \\
\hline $\operatorname{PER}(Y)-R O A\left(X_{2}\right)$ & 0.709 & 0.5029 & 1.757 & 1.75305 & 0.018841 & 0.05 \\
\hline $\begin{array}{l}\text { PER (Y)-FIRM SIZE } \\
\left(\mathrm{X}_{3}\right)\end{array}$ & 0.623 & 0.3885 & 1.806 & 1.75305 & 0.015100 & 0.05 \\
\hline
\end{tabular}

Sumber: Secondary Data, diproses dengan Aplikasi SPSS versi 25 for windows release.

Pada Tabel 5.3 di atas menggambarkan bahwa secara Partial:

a. Nilai korelasi (R) pada:

1) Pengaruh DER Terhadap PER sebesar 0.732 menunjukan 
kekuatan tinggi (0.70-0.89) bersifat positif.

2) Pengaruh ROA Terhadap PER sebesar 0.709 menunjukan kekuatan tinggi (0.70-0.79) bersifat positif.

3) Pengaruh Firm Size Terhadap PER sebesar 0.623 menunjukan kekuatan moderat (0.40-0.69) bersifat positif.

b. Nilai Korelasi Determinasi $\left(\mathrm{R}^{2}\right)$ pada:

1) Pengaruh DER Terhadap PER sebesar 0.5361 menunjukan $53.61 \%$ PER bergantung pada DER. Sedangkan $46.39 \%$ nya (100\%-53.61\%) PER dipengaruhi oleh Variabel Lain yang tidak diteliti pada penelitian ini.

2) Pengaruh ROA Terhadap PER sebesar 0.5029 menunjukkan $50.29 \%$ PER bergantung pada ROA. Sedangkan $49.71 \%$ nya (100\%-50.29\%) PER dipengaruhi oleh Variabel Lain yang tidak diteliti pada penelitian ini.

3) Pengaruh Firm Size Terhadap PER sebesar 0.3885 menunjukkan $38.85 \% \quad$ PER bergantung pada Firm Size. Sedangkan $61.15 \%$ nya $(100 \%$ $38.85 \%)$ PER dipengaruhi oleh Variabel Lain yang tidak diteliti pada penelitian ini.

c. Nilai thitung pada:

1) Pengaruh DER Terhadap PER sebesar 1.813 lebih besar ketimbang $\mathrm{t}_{\text {TABEL }}$ sebesar 1.75305. Ini menunjukan $\mathrm{Ho}_{5}$ ditolak sedangkan $\mathrm{Ha}_{5}$ diterima. Artinya DPR mampu memoderasi Pengaruh DER Terhadap PER.

2) Pengaruh ROA Terhadap PER sebesar 1.757 lebih besar ketimbang $\mathrm{t}_{\mathrm{TABEL}}$ sebesar 1.75305. Ini menunjukan $\mathrm{Ho}_{6}$ ditolak sedangkan $\mathrm{Ha}_{6}$ diterima. Artinya DPR mampu memoderasi Pengaruh ROA Terhadap PER.
3) Pengaruh Firm Size Terhadap PER sebesar 1.806 lebih besar ketimbang $\mathrm{t}_{\mathrm{TABEL}}$ sebesar 1.75305. Ini menunjukan $\mathrm{Ho}_{7}$ ditolak sedangkan $\mathrm{Ha}_{7}$ diterima. Artinya DPR mampu memoderasi Pengaruh Firm Size Terhadap PER.

d. Nilai Asymptotic Significancypada:

1) Pengaruh DER Terhadap PER sebesar 0.018957 lebih kecil ketimbang 0.05. Ini menunjukan $\mathrm{Ho}_{5}$ ditolak sedangkan $\mathrm{Ha}_{5}$ diterima. Artinya DPR mampu memoderasi Pengaruh DER Terhadap PER.

2) Pengaruh ROA Terhadap PER sebesar 0.018841 lebih kecil ketimbang 0.05. Ini menunjukan $\mathrm{Ho}_{6}$ ditolak sedangkan $\mathrm{Ha}_{6}$ diterima. Artinya DPR mampu memoderasi Pengaruh ROA Terhadap PER.

3) Pengaruh Firm Size Terhadap PER sebesar 0.015100 lebih kecil ketimbang 0.05. Ini menunjukan $\mathrm{Ho}_{7}$ ditolak sedangkan $\mathrm{Ha}_{7}$ diterima. Artinya DPR mampu memoderasi Pengaruh Firm Size Terhadap PER.

\section{Multiple Regression AnalysisSebelum Moderasi}

Tabel 5.4.

Hasil Multiple Regression Analysis Model Sebelum Moderasi

(Observasi $=4$ emiten $\mathrm{x} 4$ variabel $)$

\begin{tabular}{|l|l|l:l:l:l|}
\hline VARIABEL & $\beta$ & FHItung & $\begin{array}{l}\mathrm{F}_{\mathrm{TAB}} \\
\mathrm{EL}\end{array}$ & $\begin{array}{l}\text { Asymptotic } \\
\text { Significanc }\end{array}$ & 0.05 \\
\hline DER $\left(\mathrm{X}_{1}\right)$ & 0.6678 & 6.162308 & 3.49 & 0.005489 & 0.05 \\
\hdashline $\left.\mathrm{ROA}_{2}\right)$ & 0.4279 & & & & 0.05 \\
\hline $\begin{array}{l}\text { FIRM SIZE } \\
\left(\mathrm{X}_{3}\right)\end{array}$ & 0.0613 & & & & 0.05 \\
\hline
\end{tabular}

Sumber: Secondary Data, diproses dengan Aplikasi SPSS versi 25 for windows release

Pada Tabel 5.4 di atas dapat dijelaskan bahwa:

a. Dari perspektif perolehan nilai Slop atau Regression Coefficient maka: 1) $\beta_{1}$ sebesar 0.6678 ; 2) $\beta_{2}$ sebesar 0.4279 ; dan 3) $\beta_{3}$ sebesar 0.0613 .

b. Dari perspektif perolehan nilai $F_{\text {HITUNG }}$ sebesar 6.1623 lebih besar 
ketimbang $\mathrm{F}_{\mathrm{TABEL}}$ sebesar 3.49. Ini menunjukan bahwa $\mathrm{Ho}_{4}$ ditolak sedangkan $\mathrm{Ha}_{4}$ diterima. Artinya DPR mampu memoderasi Pengaruh DER, ROA dan Firm Size Terhadap PER.

c. Dari perspektif perolehan Asymptotic Significancy sebesar 0.005489 lebih kecil ketimbang 0.05. Ini menunjukan bahwa $\mathrm{Ho}_{4}$ ditolak sedangkan $\mathrm{Ha}_{4}$ diterima. Artinya Terdapat Pengaruh DER, ROA dan Firm Size Terhadap PER.

DER $\left(\mathrm{X}_{1}\right)$ merupakan predictor dominant ketimbang ROA dan Firm Size. Karena perolehan nilai Slop atau Regression Coefficient sebesar $\quad 0.6678 \quad$ tertinggi ketimbang nilai Slop atau Regression Coefficient pada ROA sebesar 0.4279 dan Firm Size sebesar 0.0613 .

5. Multiple Regression AnalysisSetelah Moderasi

Tabel 5.5.

Hasil Multiple Regression Analysis Model Setelah Moderasi

(Observasi $=4$ emiten $\times 5$ variabel)

\begin{tabular}{|l|l|l|l|l:l|}
\hline VARIABEL & $\beta$ & FHITUNG & $\begin{array}{l}\mathrm{F}_{\mathrm{TAB}} \\
\mathrm{EL}\end{array}$ & $\begin{array}{l}\text { Asymptotic } \\
\text { Significanc } \\
y\end{array}$ & 0.05 \\
\hline DER $\left(\mathrm{X}_{1}\right)$ & 0.7205 & 3.467528 & 3.06 & 0.030134 & 0.05 \\
\hdashline $\left.\mathrm{ROA}_{2}\right)$ & 0.2148 & & & & 0.05 \\
\hline $\begin{array}{l}\text { FIRM SIZE } \\
\left(\mathrm{X}_{3}\right)\end{array}$ & -0.0950 & & & 0.05 \\
\hline
\end{tabular}

Sumber: Secondary Data, diproses dengan Aplikasi SPSS versi 25 for windows release.

Pada Tabel 5.5 di atas dapat dijelaskan bahwa:

a. Dari perspektif perolehan nilai Slop atau Regression Coefficient maka: 1) $\beta_{1}$ sebesar 0.7205 ; 2) $\beta_{2}$ sebesar 0.2148 ; dan 3) $\beta_{3}$ sebesar -0.0950 .

b. Dari perspektif perolehan nilai FHITUNG $_{\text {situr }} 3.467528$ lebih besar ketimbang $\mathrm{F}_{\mathrm{TABEL}}$ sebesar 3.06. Ini menunjukan bahwa $\mathrm{Ho}_{8}$ ditolak sedangkan $\mathrm{Ha}_{8}$ diterima. Artinya Terdapat Pengaruh DER, ROA dan Firm Size Terhadap PER.

c. Dari perspektif perolehan Asymptotic Significancy sebesar 0.005489 lebih kecil ketimbang 0.05. Ini menunjukan bahwa $\mathrm{Ho}_{8}$ ditolak sedangkan $\mathrm{Ha}_{8}$ diterima.
Artinya DPR mampu memoderasi Pengaruh secara simultant DER, ROA dan Firm Size Terhadap PER.

Pengujian hipotesis tersebut di atas sekaligus mempertegas uji beda yaitu DER $\left(\mathrm{X}_{1}\right)$ merupakan predictor dominant ketimbang ROA dan Firm Size. Karena perolehan nilai Slop atau Regression Coefficient DER sebesar 0.7205 tertinggi ketimbang nilai Slop atau Regression Coefficient pada ROA sebesar 0.2148 dan Firm Size sebesar 0.0950

6 Komparasi antara Sebelum dan Setelah Moderasi

\section{a. Moderate Regression Analysis ModelsecaraPartial}

Tabel 5.6.

Sebelum dan SetelahModerate Regression Analysis Model Secara Partial

\begin{tabular}{|l|l|l|l|l|}
\hline \multirow{2}{*}{ VARIABEL } & $\begin{array}{l}\text { SEBELU } \\
\mathbf{M}\end{array}$ & $\begin{array}{l}\text { SETEL } \\
\mathbf{A H}\end{array}$ & $\begin{array}{l}\text { SEBELU } \\
\mathbf{M}\end{array}$ & $\begin{array}{l}\text { SETEL } \\
\mathbf{A H}\end{array}$ \\
\cline { 2 - 5 } & $\mathbf{R}$ & $\mathbf{R}$ & $\mathbf{R}^{2}$ & $\mathbf{R}^{\mathbf{2}}$ \\
\hline DER-PER & 0.592 & 0.732 & 0.3508 & 0.5361 \\
\hline ROA-PER & 0.676 & 0.709 & 0.4576 & 0.5029 \\
\hline $\begin{array}{l}\text { IIRM SIZE- } \\
\text { PER }\end{array}$ & 0.230 & 0.623 & 0.0529 & 0.3885 \\
\hline
\end{tabular}

Sumber: Secondary Data, diproses dengan Aplikasi SPSS versi 25 for windows release.

Pada Tabel 5.6 di atas dapat dijelaskan bahwa:

1) Pada Pengaruh DER Terhadap PER, DPR mampu memoderasi dengan memperkuat DER Terhadap PER. Ini ditunjukan dengan perolehan Nilai Koefisien Korelasi dan Korelasi Determinasi. Dalam hal ini, ada penambahan kekuatan Koefisien Korelasi dari 0.592 meningkat menjadi 0.732. Kemudian, kekuatan Korelasi Determinasi dari 0.3508 meningkat menjadi 0.5361 .

2) Pada Pengaruh ROA Terhadap PER, DPR mampu memoderasi dengan memperkuat Firm Size Terhadap PER. Ini ditunjukan dengan perolehan Nilai Koefisien Korelasi dan Korelasi Determinasi. Dalam hal ini, ada penambahan kekuatan Koefisien Korelasi dari 0.230 meningkat menjadi 0.623. Kemudian, 
kekuatan Korelasi Determinasi dari 0.0529 meningkat menjadi 0.3885 .

3) Pada Pengaruh Firm Size Terhadap PER, DPR mampu memoderasi dengan memperkuat ROA Terhadap PER. Ini ditunjukan dengan perolehan Nilai Koefisien Korelasi dan Korelasi Determinasi. Dalam hal ini, ada penambahan kekuatan Koefisien Korelasi dari 0.676 meningkat menjadi 0.709. Kemudian, kekuatan Korelasi Determinasi dari 0.4576 meningkat menjadi 0.5029 .

b. Moderate Regression Analysis ModelsecaraSimultant

Tabel 5.7.

Sebelum dan SetelahModerate Regression Analysis Model Secara Simultant

\begin{tabular}{|l|l|l|}
\hline \multirow{2}{*}{$\begin{array}{l}\text { VARIAB } \\
\text { EL }\end{array}$} & $\begin{array}{l}\text { SEBELU } \\
\mathbf{M}\end{array}$ & $\begin{array}{l}\text { SETELA } \\
\text { H }\end{array}$ \\
\cline { 2 - 3 } & $\boldsymbol{\beta}$ & $\boldsymbol{\beta}$ \\
\hline DER & 0.6678 & 0.7205 \\
\hline ROA & 0.4279 & 0.2148 \\
\hline $\begin{array}{l}\text { FIRM } \\
\text { SIZE }\end{array}$ & 0.0613 & -0.0950 \\
\hline
\end{tabular}

Sumber: Secondary Data, diproses dengan Aplikasi SPSS versi 25 for windows release

Pada Tabel 5.7 menunjukan bahwa

1) Nilai Slop atau Regression Coefficient pada DER ada peningkatan kekuatan dari 0.6678 menjadi 0.7205. Ini menunjukkan secara Simultant, DPR mampu memoderasi dengan memperkuat Pengaruh DER Terhadap PER.

2) Nilai Slop atau Regression Coefficient pada ROA terjadi pelemahan kekuatan dari 0.4279 menjadi 0.2148. Ini menunjukkan secara Simultant, DPR mampu memoderasi dengan memperlemah Pengaruh ROA Terhadap PER.

3) Nilai Slop atau Regression Coefficient pada Firm Size terjadi pelemahan kekuatan dari 0.0613 menjadi -0.0950. Ini menunjukkan secara Simultant, DPR mampu memoderasi dengan memperlemah Pengaruh Firm Size Terhadap PER.

\section{SIMPULAN}

Kesimpulan dari penelitian ini adalah bahwa:
1. Secara Partial Terdapat Pengaruh DER, ROA, Firm Size Terhadap PER

2. Setelah dilakukan Moderate Regression Analysis secara Partial maka DPR mampu memoderasi berupa penambahan kekuatan Pengaruh DER, ROA, Firm Size Terhadap PER.

3. Secara Simultant, Terdapat Pengaruh DER, ROA, Firm Size Terhadap PER.

4. Setelah dilakukan Moderate Regression Analysis secara Simultant, maka DPR mampu memoderasi baik penambahan kekuatan maupun memperlemah kekuatan. Dalam hal ini yang mengalami penambahan kekuatan adalah DER Terhadap PER. Sedangkan yang mengalami perlemahan kekuatan adalah ROA dan Firm Size Terhadap PER.

5. DER merupakan predictor dominant baik sebelum maupun setelah dilakukan Moderate Regression Analysis. Dengan demikian pengelolaan hutang dan ekuitas merupakan suatu hal yang penting untuk diperhatikan oleh jajaran manajemen. Mengingat DER merupakan cerminan Struktur Modal.

\section{DAFTAR PUSTAKA}

Baridwan, Zaki. 2000. Intermediate Accounting. Yogyakarta. BPFE-UGM.

Bringham, Eugene and Joel F. Houston. 2006. Fundamental of Financial Management. Jakarta. Erlangga. 2010. Essentials of

Financial Management. Jakarta. Salemba Empat

Hanafi, M. M. 2004. Manajemen Keuangan. Yogyakarta. Badan Penerbit Fakultas Ekonomi Universitas Gajah Mada.

Husnan, Suad. 2008. Manajemen Keuangan: Teori dan Penerapan Yogyarkarta. Badan Penerbit Fakultas Ekonomi Universitas Gajah Mada.

Istijanto, Oei. 2009. Aplikasi Praktis Riset Pemasaran: Cara Praktis Meneliti Konsumen dan Pesaing. Jakarta. Gramedia Pustaka Utama.

Margaretha, Farah. 2005. Teori dan Aplikasi Manajemen Keuangan. Jakarta. Garsindo. 2014. Dasar Dasar Manajemen Keuangan. Jakarta. Dian Rakyat.

Michell Suharli. 2007. "Pengaruh Profitability dan Investment Opportunity Set Terhadap Kebijakan Deviden Tunai 
dengan Likuiditas Sebagai Variabel

Penguat," Jurnal Akuntansi Dan

Keuangan, Vol. 9. No. 1, Mei. 2007. Hlm.

9-17.

Munawir. S. 2010. Analisa Laporan

Keuangan. Yogyakarta. Liberty

Riyanto, Bambang. 2008. Dasar-dasar Pembelanjaan Perusahaan. Yogyakarta. BPFE- UGM.

Sandjojo, Nidjo. 2011. Metode Analisis Jalur dan Aplikasinya. Jakarta. Pustaka Sinar Harapan

Sudarmanto, R. Gunawan. 2005. Analisis Regresi Linear Berganda dengan SPSS. Yogyakarta. Graha Ilmu.

Sugiyono. 2007. Statistik Untuk Penelitian. Bandung. Alphabet.

2008. Metode Penelitian Pendidikan. Bandung. Alphabet.

Sundjaja, Ridwan dan Inge Barlin. 2010. Manajemen Keuangan. Jakarta. Literata Lintas Media.

Sujoko dan U. Soebiantoro. 2007. "Pengaruh Struktur Kepemilikan Saham, Leverage, Faktor ntern dan Faktor ekstern terhadap Nilai Perusahaan." Jurnal Manajemen dan Kewirausahan. Vol. 9. No 1. Maret. 2007. Hlm. 41-48.

Torang, Syamsir. 2012. Organisasi dan Manajemen (Perilaku, Struktur, Budaya dan Perubahan Organisasi. Bandung. Alfabeta 